\title{
Between Citizenship and Prisons: Criminalizing LGBTphobia in Brazil
}

\author{
Alexandre Martins \\ Faculty of Philosophy, Languages and Human Sciences, University of São Paulo \\ 717, Lago St São Paulo, São Paulo, Brazil
}

The research was financed by CNPq - National Council for Scientific and Technological Development (Conselho Nacional de Desenvolvimento Científico e Tecnológico).

\section{Abstract}

This article aims at understanding, from the case of the criminalization of LGBTphobia in Brazil, how criminalizing demands were articulated by social movements with the defense of democracy and human rights. Considering that Brazilian LGBT activism has grown in struggles against the repression of the criminal justice system towards sexual and gender dissidents, we intend, at first, to understand how demands for criminalization policies arose among activists. Departing from queer criminological studies that have analyzed how gender and sexuality structure prisons and the criminal justice system, we reflect on how prisons and prison struggles have become structuring features of contemporary sexual politics. From this case, at last, we seek to illuminate aspects of the historical process underway in Brazil in the last decades in which democratization has gone hand in hand with the expansion of the criminal justice system and mass incarceration. The object of this study is the speeches of the hegemonic groups in the Brazilian LGBT movement, in order to investigate in them how demands for criminalization and incarceration were built. Thus, we are based on an empirical analysis of the documents produced by Brazilian LGBT activism since the $1980 \mathrm{~s}$, as manifestos, records of national meetings and law projects. In following the rising and rooting of this agenda, we argue that not only has LGBT phobia become a problem of crime and prison, but LGBT struggles have become criminalizing and carceral.

Keywords: crime; LGBT movement; democracy; criminalizing rationality

DOI: $10.7176 /$ RHSS/11-11-10

Publication date:June $30^{\text {th }} 2021$

\section{Introduction}

From queer criminological inquiries about queer investments in punishment (Lamble, 2013) and its intertwined relations with the spreading of neoliberal rationality in all social spheres (Dardot Laval, 2016), we frame the criminalization of LGBTphobia in Brazil as a case study of these social phenomena. The hegemonic activisms of sexual and gender dissidents started to guide criminalizing demands as the result of a specific and contingent historical process: that of Brazilian redemocratization in neoliberal and punitive turn. Instead of normalizing this historical present as the only possibility of struggles for citizenship, the brief reconstruction articulated in this article, based on the analysis of documents of LGBT activism, intends to outline how it became possible for these struggles to become criminalizing. It seeks to point out, thus, how that which in the early years of homosexual activism was not part of the horizon of expectations of the struggles became a central and nonnegotiable demand in the process of citizenship of the LGBT population.

Criminalizing and punishing emerged as if they were inescapable measures not only to combat violence and the formation of LGBT citizenship, but to consolidate democracy in Brazil meanwhile the formation of mass incarceration in Brazil. As we show in the article, the criminalization of LGBTphobia has taken a prominent place in the social movement agenda linked to struggles for democratization.

\section{Criminalizing LGBTphobia in Brazil}

In the 1970s, when the first Brazilian homosexual groups were forged, the agenda for the criminalization of homophobia did not figure as a demand to combat violence - with greater emphasis on measures to combat police and state violence against sexual and gender dissidents, which was the center of the first street protest by homosexual activists in São Paulo in 1980. Since the 1st Encounter of Homosexual Militants in 1979, the idea of including in the then 1967 Constitution the prohibition of discrimination for "sexual option" had been presented, an agenda that would be taken as inclusion of non-discrimination for "sexual orientation" in the National Assembly Constituent in 1987 as part of the strategy to guarantee civil rights to homosexuals (Camara da Silva, 1993).

It was in the $1980 \mathrm{~s}$ that the first attempts to criminalize sexual discrimination among some leaders of homosexual activism were invented, who tried between 1984 and 1985 to present a criminalizing bill in Federal Chamber of Deputies (Martins, 2020). The first time, however, that, in fact, a bill was presented that proposed to make discrimination based on sexual orientation a crime, it was in 1999 with 1904/1999 bill by Deputy Nilmário Miranda (PT), which aimed at adding "sexual orientation" to the Racism Act of 1989, which aims at 
incarceration, ranging from one to five years according to the conduct practiced.

Less than six months after the presentation of this bill, in São Paulo, on February 6, 2000, Edson Neris was murdered by skinheads while walking around Republica Square hand in hand with another man. Framed as a "hate crime", the case had great public repercussions and was mobilized to propose the first version of $5003 / 2001$ bill. This project would acquire a criminal character in its 2005 substitute, aiming to determine crimes resulting from discrimination or prejudice of gender, sex, sexual orientation and gender identity and aiming at the penalty of imprisonment for periods of one year to three or two to five years. Since 2004, after ABGLT (Lesbian, Gay, Bisexual, Travesti and Transexual Brazilian Association) chose to prioritize the approval of the criminalization of homophobia in legislative activism, the criminalizing strategy has become deeply rooted in the activism and it has become the flagship of broad sectors of the movement. The 5003/01 bill, approved in 2006 in the Federal Chamber, passed as bill PLC 122/06 in the Senate until it was filed in 2014. During this process, it was articulated the allegations of LGBTfobia violence to the supposed need to criminalize LGBTphobia as a way of guaranteeing citizenship.

In face of the difficulties to approve PLC 122 in the Legislative, pressure strategies on the Judiciary were formulated in 2010 with the presentation of lawsuits, MI 4733 in 2012 and ADO 26 in 2013. They gained new breath in the arena public debates in 2018 and 2019 with the announcement of the trial in the Supreme Federal Court, which would mobilize different LGBT activists either in advocacy in the STF, or in internet campaigns that spelled out \#ÉCrimeSim (\#YesItIsCrime) and \#CriminalizaSTF (\#CriminalizeSupremeCourt). On June 13, 2019, at the hands of the ministers of the Supreme Federal Court, homophobia and transphobia were then criminalized in Brazil.

From this trajectory, certain elements of the years 2000 and 2010 stand out that point to the way in which criminal policy has become the central and non-negotiable sphere of mobilizations for LGBT citizenship. Although it was in 2004 the first decision that criminalization would be central to institutional activism, it continued as the flagship of hegemonic groups for the next fifteen years, both in legislative advocacy and in strategic litigation, as indicated by the practices and articulations prioritized in the National Congress and Supreme Court around LGBT rights.

The continued commitment to this demand for more than a decade indicates that the priority of crime figures has taken root in hegemonic activism strategies. Since 2007, it was no longer a tactically easy agenda to be approved, but it would continue to be presented as necessary and non-negotiable, both in more "conservative" scenarios (as in 2019) and in more "progressive" scenarios (as in 2008). From this angle, it was no longer a tactic or "conjunctural response", but a hegemonic strategy of institutionalized activism.

Criminalization was reiterated as the "flagship" in the registered debates of the National LGBT Meetings (being made a top priority since 2005) and the National LGBT Public Policy Conferences (with a notable request made to Lula in 2008 by then president of ABGLT to "do any business" to approve criminalization). Despite the controversies surrounding the priority of this agenda, its continuity as a flagship would be stamped in the title of the 3rd National LGBT Conference "For a Brazil that criminalizes violence against lesbians, gays, bisexuals, transvestites and transsexuals". An emblematic episode of this priority status of criminalization within public policies took place in June 2013 when an LGBT leadership agreed not to publicly criticize the absence of antiLGBTphobia educational policies in the name of criminalizing articulations, having stated "now there is no more talking about anti-homophobia kit, now it's PLC 122" (Irineu, 2016). The criminalization strategy, therefore, in certain constellations, eclipsed other demands explicitly, such as anti-LGBT phobic education.

The LGBT struggle, in addition to national meetings, legislative and judicial advocacy, began to build in crime frames also when LGBTs took to the streets to protest, as in the already consolidated LGBT Pride Parades. At least those of the two largest Brazilian urban centers started to demand criminalization in their themes - in 2007, in Rio de Janeiro, with "Criminalization of homophobia now!" and, in São Paulo, with "Homophobia is a crime! Sexual rights are human rights" in 2006; "Homophobia can be cured: Education and Criminalization" in 2012 and "Winning country is a country without homolesbotransphobia: Enough deaths! Criminalization now! For the approval of the Gender Identity Law!" in 2014. Marching, in large urban centers at Paradas do Pride or at the Esplanada dos Ministérios, thus became a struggle to criminalize themselves.

In the fight against LGBTphobia in Brazil, not only was the framing of LGBTphobic violence as a "crime" a strategy that has been present among some leaders since the $1980 \mathrm{~s}$, but it has consolidated and taken root since the mid-2000s the framing of LGBT policy as a policy for "criminalization" and "criminal punishment". The centrality built around criminalization since 2004 when it became the flagship of hegemonic activism and its prominent roots since 2007, with the prioritization of this trench of struggle in public struggles against conservative religious activisms point to a transformation in LGBT politics in the mid-2000s. It was only at that moment that the horizons of possibilities of struggles for LGBT citizenship were largely normalized that they would be inexorably criminalizing. 


\section{Crime and citizenship}

The centrality of criminalizing demands becomes intelligible within the process of democratization, neoliberalization and punitive expansion in Brazil, in which, not only the punitive demands, but the demands for representation, participation and citizenship converged between neoliberal projects and the agendas of social movements (Dagnino, 2004). It was in the democratic period (since 1988) that most criminal laws against discrimination and prejudice were formulated and approved (Masiero, 2018). In addition to the convergence of the terms of political demands, the very forms of organization were an effect of such convergences, making possible and limitating the hegemonic forms of LGBT struggles of that period.

Linked to the process of democratization and neoliberalization in Brazil, LGBT sexual citizenship was built in two moments. In the first, since the 1980s, through health policies, there was the construction of a population as a subject of rights through the AIDS preventive system - fundamental for the transformation of LGBT policy to the terms of NGOs; and, in a second moment, through public human rights policies, especially the "denunciation of violence and discrimination motivated by sexual orientation and / or gender identity; and actions to affirm identities and broad dissemination and information on LGBT human rights "(Irineu, 2016, 224225).

In the 1990s, during the FHC governments, the form of non-governmental organizations, in a neoliberal and social democratic hybrid, converted several activist groups to the form $\mathrm{f}$ an "organization 'specialized' in providing 'social services' in defense of sexual and gender diversity", under the scrutiny ongoing "economic analysis" of goals to be efficiently accomplished (Toitio, 2016). In the Lula governments (2003-2010), a distinct social and neoliberal hybrid was articulated through the form of "vigilant collaboration" (Toitio, 2016), in which institutional participation was privileged through advocacy within its limits set by the "social policies" model and "citizenship by consumption" characteristic of that period.

At these different moments in the process of building LGBT citizenship in Brazil, there were public policies to combat violence within neoliberal social frameworks regarding the criminalizing anti-discrimination demand. Both were made possible within the "limits" of social policies in neoliberalism, which were naturalized by hegemonic activisms as insurmountable (Toitio, 2016). At the end of the 2010s, mainly with Bolsonaro's government, the resurgence of authoritarianism and the public invalidation of LGBTphobia as a social issue, linked to the increase in the dismantling of LGBT public policies, would close most of the doors to public policies and LGBT rights in the Legislative and in the federal government.

\section{Conclusion}

As an effect of the trajectory presented in this article, the bet on the criminalizing strategy in the 2000s forged a criminalizing shift in the priorities of activism: criminalization has become a non-negotiable demand for LGBT activisms organized in NGOs and in a "vigilant collaboration" with the State. Although it has never been constituted as a unique agenda for confronting LGBTphobic violence, since other demands of public policies also constituted hegemonic activist discourses, the demand for criminalization has been, since the mid-2000s, if not openly prioritized, eclipsing other agendas, while least at the top of the priority list. The notion of crime therefore became, in the years 2000 and 2010, a privileged way of building policies to combat violence and to demand citizenship. It has become normalized, therefore, that fighting LGBTphobia and building rights for the LGBT population would involve criminalizing violence and punishing and imprisoning LGBTphobic individuals. In the criminalizing-neoliberal-democratic Brazilian constellation, criminalization has emerged as an "efficient" and "feasible" measure to combat violence. Within these horizons, the punishment of "criminals", the fight against impunity and the legitimate emergence of "victims of crime" are linked to the strengthening of democracy in the historical post-dictatorship period. In this Brazilian hybrid in which criminalizing and democratizing went hand in hand, social justice, a grammar that is still present in these activisms, would then necessarily pass through criminal justice.

By outlining this logic from this case, we can understand how prisons continued to be claimed as a democratic device, in times of mass incarceration and of flagrant rights violation in prisons built on racist and cisheterosexist logics. In the path of Brazilian democratization, the demands of social movements, such as the LGBT, have become criminalizing, while citizenship has become centrally punitive, without the criminal justice system and the prisons becoming less anti-democratic, nor less structured by racist and cisheterosexist logics.

\section{References}

Dagnino, E. (2004). Construção democrática, neoliberalismo e participação: os dilemas da confluência perversa. Politica \& Sociedade. 5, 139-164.

Dardot, P. \& Laval, C. (2016). A nova razão do mundo: ensaio sobre a sociedade neoliberal. São Paulo: Boitempo.

Irineu, B. (2016). A política pública LGBT no Brasil (2003-2014): homofobia cordial e homonacionalismo nas tramas da participação social. Phd Thesis, Federal University of Rio de Janeiro, Rio de Janeiro. 
Lamble, S. (2013). Queer Necropolitics and the Expanding Carceral State: Interrogating Sexual Investments in Punishment. Law and Critique, v. 24, n. 3, 229-253.

Martins, A. (2020). Caminhos da criminalização da LGBTfobia no Brasil: racionalidade criminalizante, neoliberalismo e democratização. Master thesis, University of São Paulo, São Paulo.

Masiero, C. (2018). Lutas sociais e política criminal: os movimentos feministas, negro e LGBTQ e a criminalização das violências machista, racista e LGBTQfóbica no Brasil. Phd thesis, Unisinos, São Leopoldo.

Silva, C. (1993). Triângulo Rosa. A busca pela cidadania dos "homossexuais". Master thesis, Federal University of Rio de Janeiro, Rio de Janeiro.

Simon, Jonathan. (2007). Governing through crime: How the war on crime transformed American democracy and created a culture of fear. Oxford University Press.

Toitio, R. (2016). Cores e contradições: A luta pela diversidade sexual e de gênero sob o neoliberalismo brasileiro. Phd thesis, Unicamp, Campinas. 